\title{
Synthesis of Nano-Photocatalyst ZnO-Natural Zeolite to Degrade Procion Red
}

\author{
Tuty Emilia Agustina ${ }^{1 *}$, Elda Melwita ${ }^{1}$, David Bahrin ${ }^{1}$, Rianyza Gayatri ${ }^{1}$, \\ Indah Fitriany Purwaningtyas ${ }^{1}$ \\ ${ }^{1}$ Chemical Engineering Department, Faculty of Engineering, Universitas Sriwijaya, 30662, Indralaya, South \\ Sumatra, Indonesia
}

\begin{abstract}
The development of textile factories has had a significant impact on the environment because dye wastewater is difficult to degrade. The handling of textile wastewater usually involves the adsorption method, in which pollutants only transfer to another phase. As an alternative solution, a photodegradation method was developed using photocatalyst material assisted by ultraviolet irradiation. In this photodegradation method, dye substances are broken down into components that are simpler and safer for the environment. The possibility of using sunlight as a radiation source makes this a particularly promising method for countries such as Indonesia. Procion red, one of the most commonly utilized synthetic dyes in the home textile or Batik industry, was used as a model pollutant in this study. The objectives of the present research were to synthesize and characterize a nano-photocatalyst of $\mathrm{ZnO}$-natural zeolite with the capacity to degrade Procion red. This nano-photocatalyst was synthesized using the sol-gel method, by which $\mathrm{Zn}\left(\mathrm{CH}_{3} \mathrm{COO}\right)_{2} 2 \mathrm{H}_{2} \mathrm{O}$ was used as a precursor and combined with natural zeolite to increase its photocatalytic ability. The nano-photocatalyst was characterized using X-ray diffraction (XRD), scanning electron microscope/energy dispersive X-ray spectroscopy (SEM/EDX), and BrunauerEmmett-Teller (BET). The activity of nano-photocatalyst ZnO-natural zeolite was compared to $\mathrm{ZnO}$ alone and natural zeolite alone in terms of its ability to degrade Procion red. An average photocatalyst crystallite diameter of $82 \mathrm{~nm}$ was achieved, proving that a nano-sized photocatalyst of ZnO-natural zeolite was successfully synthesized. BET characterization showed that nanophotocatalyst ZnO-natural zeolite had a specific surface area of $14.84 \mathrm{~m}^{2} / \mathrm{g}$, a pore size of $32.71 \mathrm{~nm}$, and a pore volume of $0.12 \mathrm{~cm}^{2} / \mathrm{g}$. A peak Procion red degradation percentage of $96.23 \%$ was obtained using nano-photocatalyst ZnO-natural zeolite after 120 minutes of irradiation under sunlight applied to a Procion red concentration of $50 \mathrm{ppm}$.
\end{abstract}

Keywords: Nano-photocatalyst; Natural zeolite; Photodegradation; Procion red; ZnO

\section{Introduction}

The development of the textile industry has certainly had an impact on the environment, as the dye wastewater produced by this industry is difficult to degrade. Dyecontaining wastewater usually consists of non-biodegradable organic compounds that can contribute to pollution, especially in aquatic environments. However, the wastewater produced by the textile industry also contains synthetic dyes that are harmful to the environment. Procion red is one of the most commonly used synthetic dyes in the home textile or Batik industry. This synthetic dye is difficult to degrade due to the strong covalent bonds between the carbon atoms of the dye stuff and the $0, \mathrm{~N}$, or $\mathrm{S}$ atoms of the hydroxy,

${ }^{*}$ Corresponding author's email: tuty_agustina@unsri.ac.id, Tel.: +62-711-580303; Fax.: +62-711-580303 doi: 10.14716/ijtech.v11i3.3800 
amino, or thiol groups of the polymer (Hunger, 2003).

Degradation methods, such as coagulation-flocculation (Rusydi et al., 2016) and a combination of electrocoagulation and photocatalysis (Sharfan et al., 2018), have been developed for dyes in the textile industry. However, these chemical processing methods apply large quantities of chemicals and produce sludge, which must be separated at the end of process. Membrane applications are quite effective but require significant operational costs and have the disadvantage of introducing new problems, such as the production of compounds with more concentrated pollutant levels. A photodegradation method using photocatalyst materials and ultraviolet light irradiation has been developed as an alternative method (Agustina et al., 2015; Zhao et al., 2015). Among modern methods of dealing with wastewater, photodegradation is relatively inexpensive and easy to implement. Widely studied photocatalysts include metal oxide semiconductors, such as $\mathrm{ZnO}$ and $\mathrm{TiO}_{2}$. The $\mathrm{ZnO}$ semiconductor has an advantage over $\mathrm{TiO}_{2}$ because it is able to absorb the UV spectrum of the sun and quantum of light more readily than $\mathrm{TiO}_{2}$. In addition, $\mathrm{ZnO}$ is an efficient photocatalyst material for the detoxification of wastewater because it produces $\mathrm{H}_{2} \mathrm{O}_{2}$ more efficiently than other photocatalysts (Hidayanto et al., 2013; Mydeen et al., 2019). ZnO is widely used due to its cost-effectiveness, high oxidation ability, and wide availability. However, electron-hole recombination can block the photocatalytic activity of pure $\mathrm{ZnO}$.

Research has been carried out to investigate the pure photocatalytic activity of semiconductors, such as $\mathrm{ZnO}$, in degrading organic compounds, such as synthetic dyes. Photocatalyst activity can be increased through the development of supporting materials, such as natural zeolites. Natural zeolite, a cheap and locally available absorbent, has been used in the energy field and for many applications such as additives, catalysts, ion exchangers, and absorbents (Millar et al., 2016; Papa et al., 2017; Wulandari et al., 2019). Zeolite is used as a carrier molecular because its crystal structure is porous and has a large surface area, it is composed of a silica-alumina skeleton, it has a high thermal stability, and its presence is quite abundant (Wang and Peng, 2010). The pore structure of zeolite also allows it to be used as a host material (Rahman et al., 2018). Moreover, zeolite is recommended for the degradation of dye through adsorption due to its large surface area (Viswanathan, 2018). The surface area and acidity of natural zeolite could be modified easily (Suhartana et al., 2018; Wulandari et al., 2019). The present study utilized natural zeolite from West Java.

Many efforts have been made to enhance the photocatalytic performance, especially in dye degradation. Such efforts have involved making ZnO-zeolite composites by impregnation methods (Salam et al., 2018), doping ZnO nanoparticles with natural zeolite (Rahman et al., 2018), and adding noble metals, such as Ag nanoparticles (Kusdianto et al., 2019) and $\mathrm{Fe}_{3} \mathrm{O}_{4}$ (Winatapura et al., 2016). ZnO has a low capacity for adsorption as a photocatalyst, but $\mathrm{ZnO}$ photocatalysts can be combined with adsorbents, such as zeolite, to face this problem (Wismayanti, 2015). Therefore, the present study aimed to synthesize photocatalysts of nano-sized $\mathrm{ZnO}$-natural zeolites in order to utilize the adsorbent properties of natural zeolites as well as the photocatalytic properties of $\mathrm{ZnO}$. The obtained photocatalyst material was tested for photocatalyst activity in the degradation of synthetic dyes. Then, this activity was compared with the degradation of Procion red by standard ZnO and natural zeolites alone. 


\section{Methods}

\subsection{Materials}

Hydrochloric acid ( $\mathrm{HCl}), \mathrm{Zn}\left(\mathrm{CH}_{3} \mathrm{COO}\right)_{2} 2 \mathrm{H}_{2} \mathrm{O}, \mathrm{ZnO}$, ethanol, and $\mathrm{NaOH}$ were supplied by Merck and used without any further purification. Natural zeolite was derived from West Java, Indonesia (300 mesh), and Procion red was purchased from Fajar Setia in Jakarta. The natural zeolite was activated by $1 \mathrm{M} \mathrm{HCl}$ and then rinsed and dried for three hours at $220^{\circ} \mathrm{C}$. The ratio for activated natural zeolite: $1 \mathrm{M} \mathrm{HCl}$ was $100 \mathrm{~g}$ of natural zeolite : $200 \mathrm{~mL}$ of $1 \mathrm{M}$ HCl.

\subsection{Synthesis of ZnO-Natural Zeolite}

First, $45 \mathrm{~g}$ of $\mathrm{Zn}\left(\mathrm{CH}_{3} \mathrm{COO}\right)_{2} 2 \mathrm{H}_{2} \mathrm{O}$ was added to $3.32 \mathrm{~g}$ of activated natural zeolite and then dissolved in $80 \mathrm{~mL}$ of ethanol. This mixture was stirred and heated at $76^{\circ} \mathrm{C}$ in a reflux flask for two hours. Then, $225 \mathrm{~mL}$ of $2 \mathrm{M} \mathrm{NaOH}$ was added to the mixture and stirred for one hour with a magnetic stirrer. The mixture was allowed to stand for 12 hours and then filtered. The resulting precipitate was heated at $60^{\circ} \mathrm{C}$ for 24 hours and then stored in a desiccator so that it would remain dry. The $\mathrm{ZnO}$-natural zeolite composites were characterized by X-ray diffraction (XRD of Rigaku Miniflex 600), scanning electron microscope/energy dispersive X-ray spectroscopy (SEM/EDX of ZEISS EVO@ MA 10), and Brunauer-Emmett-Teller (BET).

\subsection{Photocatalyst Activity Test}

A UV reactor system furnished with a UV lamp (Evaco $15 \mathrm{~W} 254 \mathrm{~nm}$ ) was used in this study. A total of $100 \mathrm{mg}$ of ZnO-natural zeolite photocatalyst was dispersed in $25 \mathrm{~mL}$ of 50 ppm Procion red in the reactor and then placed in a shaker equipped with UV light. The photodegradation process was carried out without $\mathrm{pH}$ adjustment. The recording time started when the shaker and the UV lamp were turned on. The experiments were repeated using Procion red of different concentrations and carried out in dark conditions as well as under sunlight. For the experiments in dark conditions, the UV lamp was left off for two hours and the shaker was covered with a box coated in black low-density polyethylene (LDPE) plastic. The experiments using sunlight were carried out on a light day between 10:00 a.m. and 2:00 p.m. Samples were taken every 30 minutes for two hours and then filtered. The concentration of the Procion red was analyzed using a UV-Vis spectrophotometer at a maximum wavelength of $539 \mathrm{~nm}$. The Procion red degradation procedure was also carried out using $\mathrm{ZnO}$ and natural zeolite alone.

\section{Results and Discussion}

\subsection{Characterization of Photocatalyst ZnO-Natural Zeolite}

Characterization of photocatalyst ZnO-natural zeolite was carried out using SEM/EDX, $\mathrm{XRD}$, and BET. Figure 1a shows the SEM image of the photocatalyst. The morphology of the photocatalyst can be seen in fine clumps. The average crystallite size (D) was calculated using the highest intensity from the XRD patterns presented in Figure $1 \mathrm{~b}$ and the Scherrer formula (Equation 1) reported in previous studies (Widiyastuti et al., 2014; Vaiano et al., 2017):

$$
D=\frac{\mathrm{k} \lambda}{\mathrm{B} \cos \theta}
$$

where $k$ is the constant (0.9), $\lambda$ is the wavelength of the X-ray source $(0.15418 \mathrm{~nm}), B$ is the full width at half maximum corresponding to the XRD peaks, and $\theta$ is the peak angle. The average diameter of the photocatalyst crystallite was $82 \mathrm{~nm}$, proving that the synthesis of nano-sized photocatalysts of $\mathrm{ZnO}$-natural zeolite was accomplished successfully. Figure $1 \mathrm{~b}$ 
demonstrates the XRD pattern of the ZnO-natural zeolite. This XRD pattern is identical to ZnO peak, which exhibited diffraction peaks at $2 \theta=31.8,34.5,36.4,47.6,56.8,62.9$, and 68.2. These peaks revealed a hexagonal wurtzite structure (Balcha et al., 2016). Other peaks found at $2 \theta=9.80,13.6,22.38,25.69,26.66$, and 27.72 represented the presence of zeolite by potassium sodium calcium aluminium silicate hydrate content (Razzak et al., 2013). The EDX results confirmed that the composite consisted of $\mathrm{ZnO}$ and the elements of zeolite, as shown in Figure 2. Based on the EDX results, 10.05\% of ZnO was added to natural zeolite.

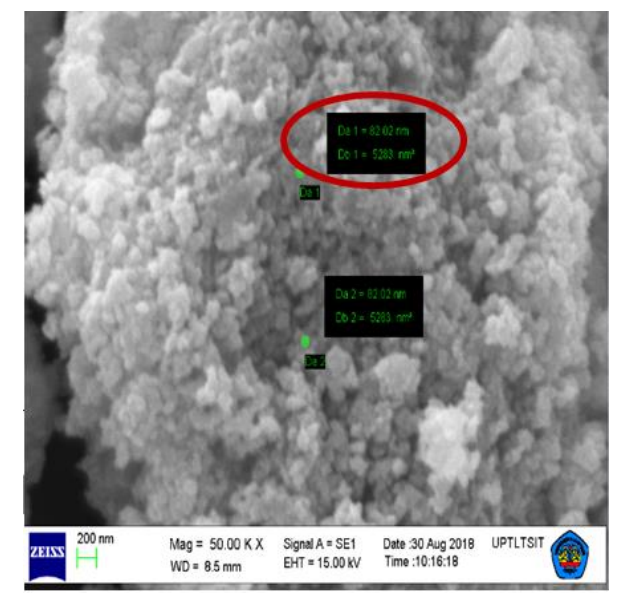

(a)

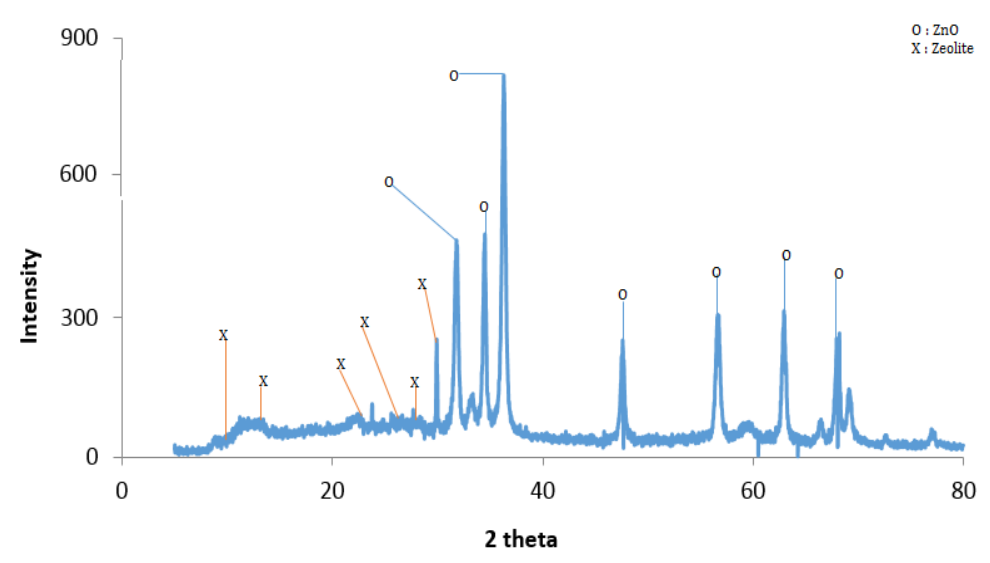

(b)

Figure 1 SEM image (a) and XRD (b) of nano-photocatalyst ZnO-natural zeolite

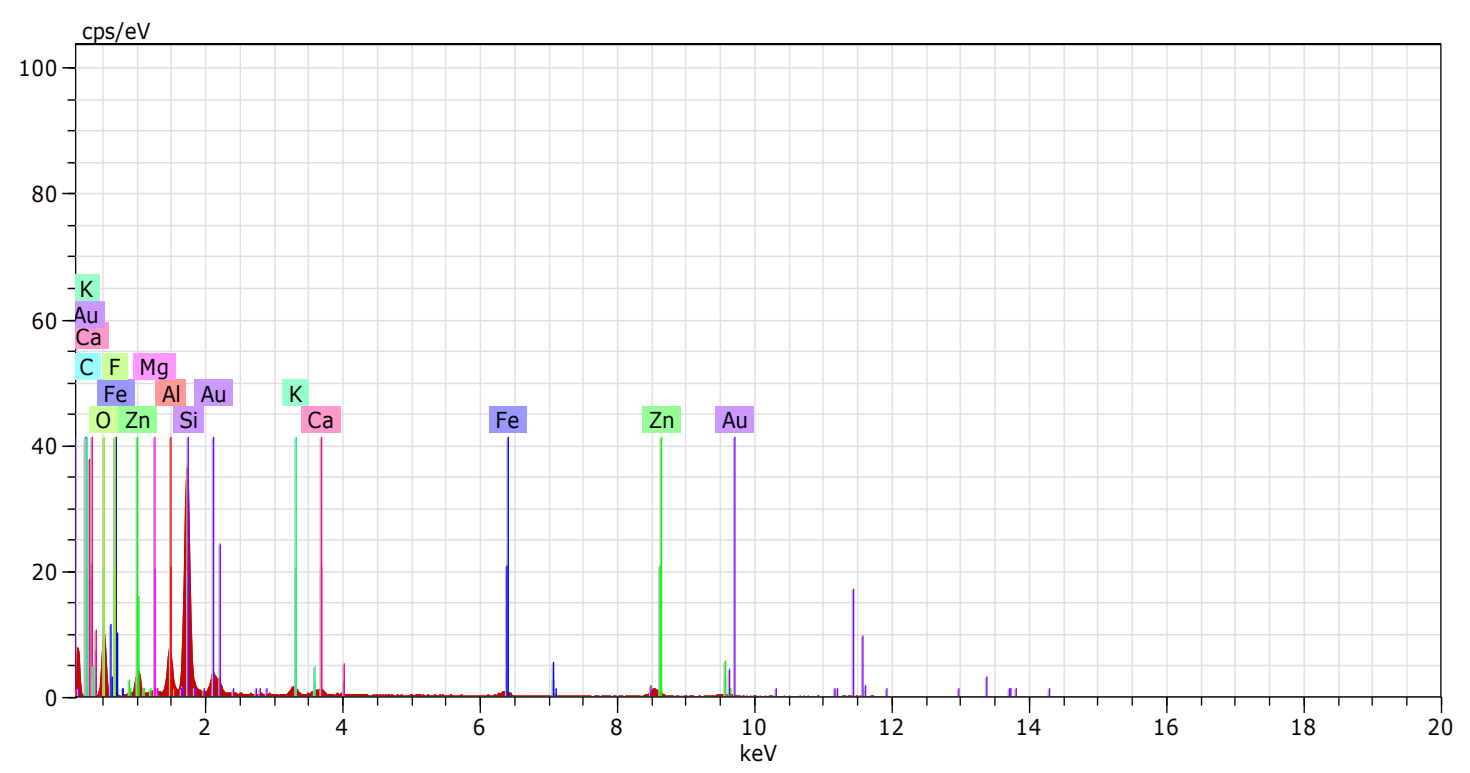

Figure 2 EDX of nano-photocatalyst ZnO-natural zeolite

Table 1 shows the results of the BET characterization. The nano-photocatalyst $\mathrm{ZnO}$-natural zeolite had a lower surface area $\left(14.85 \mathrm{~m}^{2} / \mathrm{g}\right)$ than the activated natural zeolite. $\mathrm{ZnO}$ incorporated with natural zeolites was unevenly distributed in the nano-photocatalyst ZnO-natural zeolite composite in the form of sintering or clumping. Because of this clumping, it stands to reason that ZnO entering natural zeolite would cover the pores, making the specific surface area relatively smaller (Rakhmawaty and Putra, 2011). However, the pore size of the nano-photocatalyst $\mathrm{ZnO}$-natural zeolite was significantly higher $\left(32.71 \mathrm{~m}^{2} / \mathrm{g}\right)$ than that of the activated natural zeolite $\left(4.30 \mathrm{~m}^{2} / \mathrm{g}\right)$. Furthermore, the 
pore volume of the nano-photocatalyst ZnO-natural zeolite also increased to $0.12 \mathrm{~cm}^{2} / \mathrm{g}$. This occurred because the produced $\mathrm{ZnO}$ was nano in size. As the size of a particle becomes smaller, its pore size and volume increase and thus its specific surface area decreases (Pakpahan et al., 2017).

Table 1 BET characterization results

\begin{tabular}{lccc}
\hline \multicolumn{1}{c}{ Measurement Subject } & Natural & Activated & Nano-Photocatalyst \\
& Zeolite & Natural Zeolite & ZnO-Natural Zeolite \\
\hline Specific Surface Area $\left(\mathrm{m}^{2} / \mathrm{g}\right)$ & 23.40 & 26.19 & 14.85 \\
Pore Size $\left(\mathrm{m}^{2} / \mathrm{g}\right)$ & 7.39 & 4.30 & 32.71 \\
Pore Volume $\left(\mathrm{cm}^{2} / \mathrm{g}\right)$ & 0.04 & 0.03 & 0.12 \\
\hline
\end{tabular}

\subsection{Degradation of Procion Red Synthetic Dye using a Nano-Photocatalyst}

In order to test the activity of nano-photocatalyst $\mathrm{ZnO}$-natural zeolite, it was used to degrade Procion red synthetic dye. For the sake of comparison, natural zeolite and $\mathrm{ZnO}$ were also tested separately for their abilities to degrade the synthetic dye. The concentrations of the synthetic dye ranged from 50 to $250 \mathrm{ppm}$. The highest degradation percentage of $96.23 \%$ was obtained using a Procion red concentration of 50 ppm after 120 minutes of irradiation under sunlight, as demonstrated in Figure 3. At the same time, degradation percentages of $39.31 \%$ and $91.21 \%$ were obtained using zeolite and $\mathrm{ZnO}$, respectively. High degradation percentages were also consistently obtained using nanophotocatalyst ZnO-natural zeolite at 30, 60, and 90 minutes of degradation $(93.20 \%$, $93.47 \%$, and $95.81 \%$, respectively). This finding shows that the catalytic ability of nanophotocatalyst $\mathrm{ZnO}$-zeolite assisted by sunlight irradiation is more effective than natural zeolite or $\mathrm{ZnO}$ alone. In terms of particle size, smaller particles have greater surface areas, resulting in greater interaction on the particle surface (Naimah et al., 2011). Therefore, the inclusion of nano-sized $\mathrm{ZnO}$ in the photocatalyst improved its function. Even within the first 30 minutes of exposure, the degradation percentage reached more than $90 \%$.

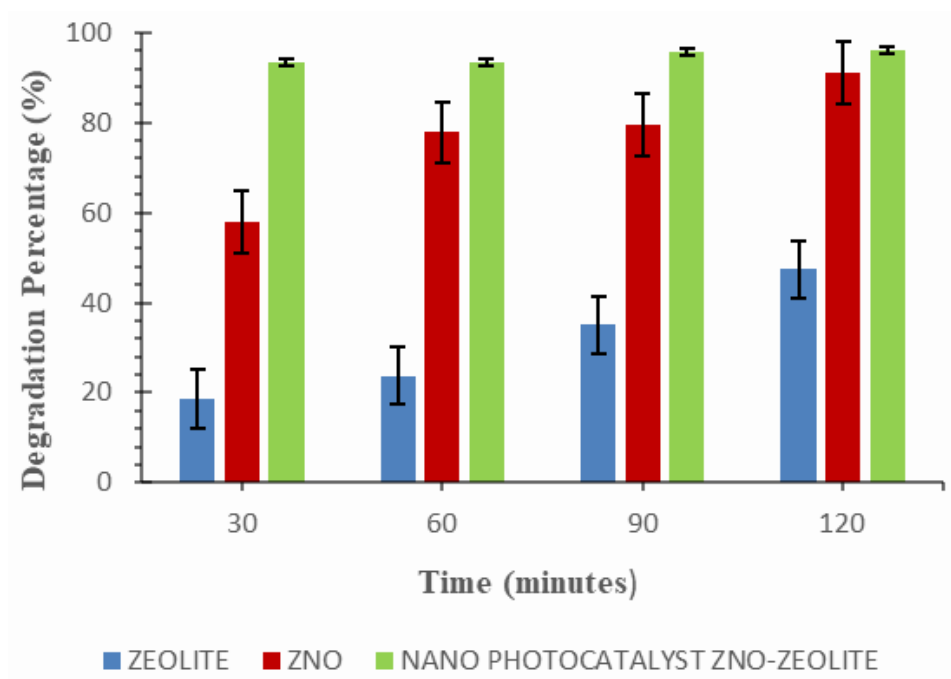

Figure 3 Degradation of 50 ppm Procion red using sunlight 


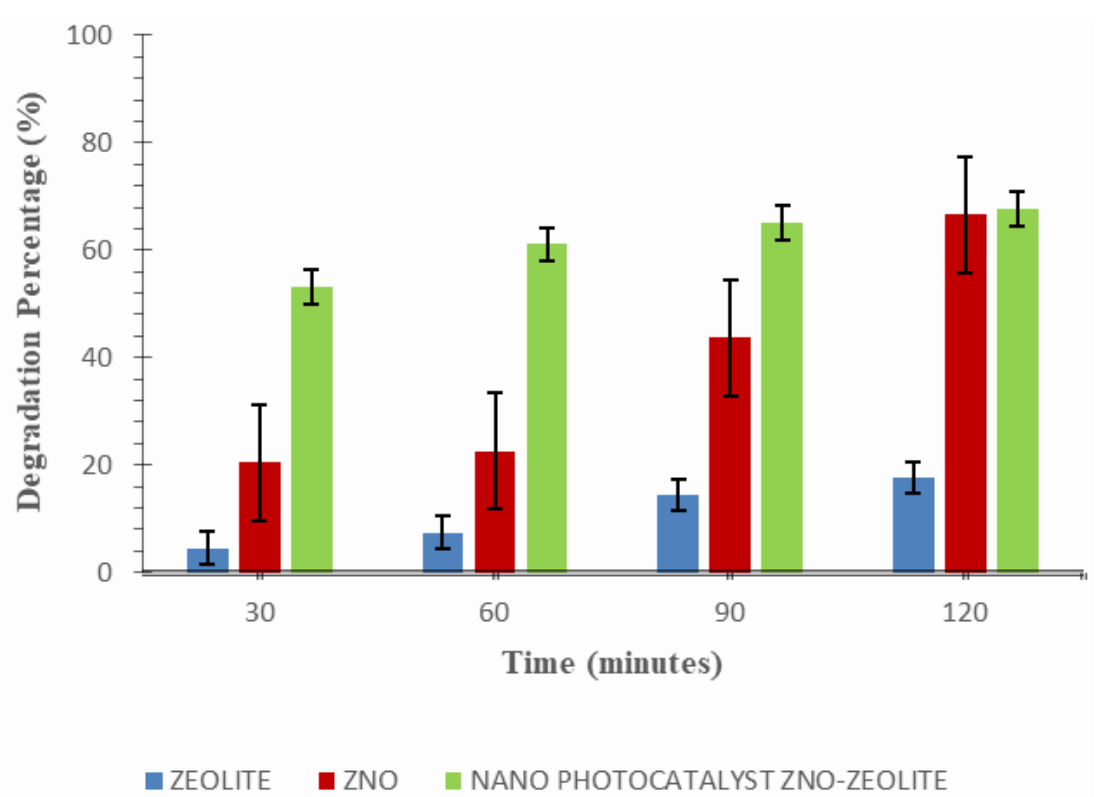

Figure 4 Degradation of 250 ppm Procion red using sunlight

Figure 4 shows that the highest percentage of $250 \mathrm{ppm}$ Procion red degradation using sunlight $(67.72 \%)$ was achieved at 120 minutes with nano-photocatalyst ZnO-natural zeolite, whereas zeolite and $\mathrm{ZnO}$ alone only accomplished $17.61 \%$ and $66.71 \%$ degradation at this point, respectively. At 30,60, and 90 minutes, peak degradation percentages of $53.22 \%, 61.13 \%$, and $65.09 \%$, respectively, were obtained using nano-photocatalyst $\mathrm{ZnO}$-natural zeolite. These results also showed that nano-photocatalyst ZnO-natural zeolite degraded Procion red more effectively than either $\mathrm{ZnO}$ or zeolite alone. Overall, nano-photocatalyst ZnO-natural zeolite produced the best degradation results for each test condition.

To determine the effect of the dye concentration, Procion red degradation was studied in the concentration range of 50-250 ppm. However, for the application of a photocatalyst in real conditions under sunlight irradiation, this paper only reported the use of the highest concentration of $250 \mathrm{ppm}$, which is closest to actual wastewater characters. The percentage of degradation obtained with $250 \mathrm{ppm}$ Procion red using sunlight irradiation is shown in Figure 4. The highest degradation percentage (67.72\%) was achieved at 120 minutes using nano-photocatalyst $\mathrm{ZnO}$-natural zeolite, whereas zeolite and $\mathrm{ZnO}$ alone only achieved $17.61 \%$ and $66.71 \%$ degradation at this point, respectively. At 30,60 , and 90 minutes, peak degradation percentages of $53.22 \%, 61.13 \%$, and $65.09 \%$, respectively, were obtained using nano-photocatalyst $\mathrm{ZnO}$-natural zeolite. However, the percent degradation obtained using $250 \mathrm{ppm}$ Procion red was lower than that obtained using $50 \mathrm{ppm}$ Procion red, likely because $250 \mathrm{ppm}$ Procion red contains a higher concentration of chemicals to be decomposed. As shown by Figures 3 and 4, increasing the Procion red concentration from $50 \mathrm{ppm}$ to $250 \mathrm{ppm}$ caused the degradation percentage to decrease from $96.23 \%$ to $67.72 \%$ or $28.51 \%$ when photocatalyst $\mathrm{ZnO}$-natural zeolite was applied after 120 minutes of irradiation. These results were in accordance with the results of a study conducted by Winatapura et al., in which photodegradation efficiency decreased from $100 \%$ to $52 \%$ when the Methylene blue dye concentration increased from 10 to $40 \mathrm{ppm}$ (Winatapura et al., 2016). In the present study, increasing the Procion red concentration from 50 to $250 \mathrm{ppm}$ decreased the average degradation percentages by $20.23 \%, 39.54$, and $32.88 \%$ for the application of zeolites alone, $\mathrm{ZnO}$ alone, and natural $\mathrm{ZnO}$-zeolite photocatalysts, respectively. 
The photocatalytic process is less effective for treating high concentrations of waste because the adsorption ability of photocatalysts is limited; therefore, increased waste concentrations cause a decrease in the rate of photocatalytic reactions (Takeda et al., 1995). This principle is in accordance with the results of the present study; for each test condition, greater concentrations of Procion red corresponded to lower percentages of degradation. The rate of dye degradation is related to the formation of $\mathrm{OH}$ radicals $(\bullet \mathrm{OH})$, which are the most important species in the degradation process. An increase in the initial concentration of Procion red causes the longer the photon path to irradiate the solution so that the photon reaching the catalyst are reduced, thereby reducing the rate of degradation. Therefore, the concentration of Procion red can affect the rate of dye degradation.

Interestingly, the photocatalyst reached optimum activity within the first 30 minutes of application to the lowest concentration of Procion red (50 ppm) for all test materials. However, the degradation percentages only slightly increased from 30 to 120 minutes of natural zeolite or $\mathrm{ZnO}$ application, as shown by Figure 3. In the degradation of Procion red at a high concentration (250 ppm), the use of photocatalyst $\mathrm{ZnO}$-natural zeolite was not optimal because the percent degradation rose only slightly until 120 minutes of reaction time; the same percent degradation was achieved by $\mathrm{ZnO}$ alone, as demonstrated in Figure 4. This finding should be taken into consideration in choosing the best material to degrade high-concentration dyes with the aid of abundant sunlight in a country such as Indonesia.

\subsection{The Effect of Irradiating Conditions on Procion Red Degradation}

To study the effects of irradiating conditions, the nano-photocatalyst was applied under three different types of irradiation. These test conditions were distinguished using UV lamps, sunlight, and a dark place as a control. The results of these tests are illustrated in Figure 5 below. The lowest concentration of Procion red solution ( $50 \mathrm{ppm}$ ) yielded the best degradation results under sunlight. This result is in agreement with the results of Salam et al. (2018), who synthesized ZnO-zeolite composites by the impregnation method and studied the effects of different light conditions (dark room, UV light, and sunlight) on the degradation of Procion red. Salam et al. (2018) found that Procion red degradation by sunlight radiation (83.96\% after 120 minutes) was greater than degradation under a UV lamp or in a dark room.

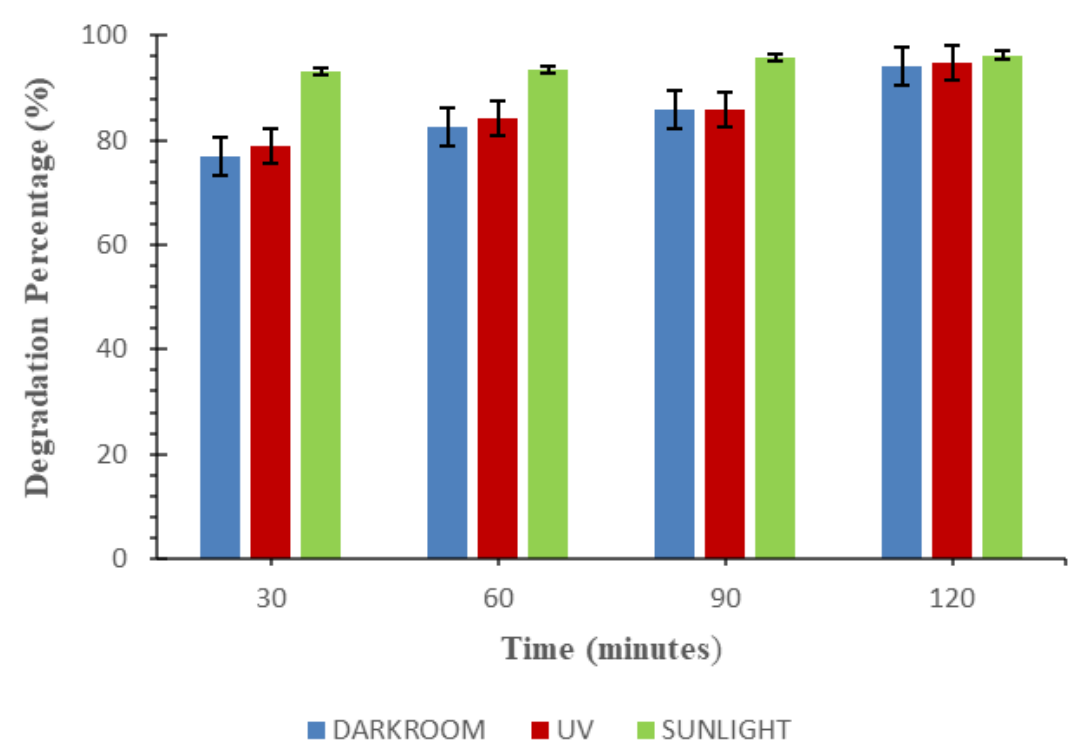

Figure 5 Degradation of 50 ppm Procion red under different light conditions 
The degradation of Procion red by the nano-photocatalyst and by $\mathrm{ZnO}$ after exposure to sunlight (approximately 555,263.64 lux) was greater than that produced under UV lamps or dark conditions. Exposure to sunlight produces faster color degradation rates, as the high energy levels emitted by UV and light rays appear to be able to excite electrons from chromophore groups (Fraditasari et al., 2015). Sunlight radiation also produces the highest degradation because the intensity of sunlight is much greater than the intensity of reactormounted UV light (Chatti et al., 2007). Sunlight also has a wider wavelength, encompassing approximately $40 \%$ of visible light and $3 \%$ of ultraviolet light. The number of visible rays reaching the active side of the photocatalyst increases the formation of hydroxyl radicals available for the photodegradation of Procion red (Charanpahari et al., 2012).

\section{Conclusions}

Nano-photocatalyst $\mathrm{ZnO}$-natural zeolite was synthesized using $\mathrm{Zn}\left(\mathrm{CH}_{3} \mathrm{COO}\right)_{2} 2 \mathrm{H}_{2} \mathrm{O}$ precursors and activated natural zeolite. Characterization of this photocatalyst showed that it was formed with an average crystallite size of $82 \mathrm{~nm}$, a specific surface area of $14.84 \mathrm{~m}^{2} / \mathrm{g}$, a pore size of $32.71 \mathrm{~nm}$, and a pore volume of $0.12 \mathrm{~cm}^{2} / \mathrm{g}$. The use of nano-photocatalyst ZnO-natural zeolite produced the highest synthetic dye degradation percentage (96.23\%) in the degradation of $50 \mathrm{ppm}$ Procion red under 120 minutes of sunlight irradiation.

\section{Acknowledgements}

The authors would like to thank LPPM Universitas Sriwijaya for funding this research through Hibah Unggulan Kompetitif of 2018. The authors also wish to acknowledge the Waste Management Technology Laboratory of the Chemical Engineering Department for providing laboratory assistance.

\section{References}

Agustina, T.E., Komala, R., Faizal, M., 2015. Application of $\mathrm{TiO}_{2}$ Nano Particles Photocatalyst to Degrade Synthetic Dye Wastewater under Solar Irradiation. Contemporary Engineering Sciences, Volume 8(34), pp. 1625-1636

Balcha, A., Yadav, O.P., Dey, T., 2016. Photocatalytic Degradation of Methylene Blue Dye by Zinc Oxide Nanoparticles Obtained from Precipitation and Sol-Gel Methods. Environmental Science and Pollution Research, Volume 23(24), pp. 25485-25493

Charanpahari, A., Umare, S., Gokhale, S.P., Sudarsan, V., Sreedhar, B., Sasikala, R., 2012. Enhanced Photocatalytic Activity of Multi-Doped $\mathrm{TiO}_{2}$ for the Degradation of Methyl Orange. Applied Catalysis A: General, Volume 443-444, pp. 96-102

Chatti, R., Rayalu, S., Dubey, N., Labhsetwar, N., dan Devotta, S., 2007. Solar-based Photoreduction of Methyl Orange using Zeolite Supported Photocatalytic Materials. Solar Energy Materials 7 Solar Cells, Volume 91, pp. 180-190

Fraditasari, R., Wardhani, S., Khunur, M.M., 2015. Degradasi Methyl Orange Menggunakan Fotokatalis $\mathrm{TiO}_{2}-\mathrm{N}$ : Kajian Pengaruh Sinar dan Konsentrasi $\mathrm{TiO}_{2}-\mathrm{N}$ (Methyl Orange Degradation using $\mathrm{TiO}_{2}-\mathrm{N}$ Photocatalyst: The Study of Effect of Irradiation and $\mathrm{TiO}_{2}-\mathrm{N}$ Concentration). Jurnal Ilmu Kimia, Volume 1(1), pp. 606-612

Hidayanto, E., Sutanto, H., Sofian, K., Arifin, Z., 2013. Pembuatan Lapisan Fotokatalis Zinc Oxide (ZnO) dengan Teknik Spray Coating dan Aplikasinya pada Pengering Jagung (Preparation of Zinc Oxide (ZnO) Photocatalyst Layer by Spray Coating Technique and Its Application in Corn Dryer). Jurnal Berkala Fisika, Volume 16, pp. 119-124

Hunger, K., 2003. Industrial Dyes: Chemistry, Properties, Applications. Weinheim: Wiley-vch Verlan GmbH \& Co. KGaA 
Kusdianto, K., Widiyastuti, W., Shimada, M., Nurtono, M.T., Machmudah, S., Winardi, S., 2019. Photocatalytic Activity of ZnO-Ag Nanocomposites Prepared by a One-step Process using Flame Pyrolysis. International Journal of Technology, Volume 10(3), pp. 571581

Millar, G., Couperthwaite, S.J., Alyuz, K., 2016. Behavior of Natural Zeolites Used for the Treatment of Simulated and Actual Coal Seam Gas Water. Journal of Environmental Chemical Engineering, Volume 4(2), pp. 1918-1928

Mydeen, S., Kottaisamy, M., Vasantha, V.S., Ramachandran, K., 2019. Photocatalytic Performances and Antibacterial Activities of Nano-ZnO Derived by Cetrimide-based Co-precipitation Method by Varying Solvents. International Journal of Innovative Technology and Exploring Engineering (IJITEE), Volume 9, pp. 2278-3075

Naimah, S., Aviandharie, S.A., Jati, B.N., Aidha, N.N., Cahyaningtyas, A.A., 2011. Degradasi Zat Warna Pada Limbah Cair Industri Tekstil Dengan Metode Fotokatalitik Menggunakan Nano Komposit $\mathrm{TiO}_{2}$-Zeolit (Degradation of Dyes in Textile Industry Wastewater by Photocatalytic Method Using $\mathrm{TiO}_{2}$-Zeolite Nano Composite).Jurnal Kimia Dan Kemasan, Volume 36(2), pp. 225-236

Pakpahan, J.K., Karo, P.K., Suroto, B.J., 2017. Studi Luas Permukaan Spesifik Zeolit Akibat Pengaruh Mikrostruktur dan Potensinya sebagai Elektrode Superkapasitor (Study of Zeolite Specific Surface Area Due to the Effects of Microstructure and its Potential as Supercapacitor Electrodes). Jurnal Teori Dan Apikasi Fisika, Volume 5(1), pp. 19-24

Papa, E., Medri, V., Amari, S., Manaud, J., Benito, P., Vaccari, A., Landi, E., 2017. Zeolite Geopolymer Composite Materials: Production and Characterization.Journal of Cleaner Production, Volume 171, pp. 76-84

Rahman, A., Nurjayadi, M., Wartilah, R., Kusrini, E., Prasetyanto E.A., Degermenci, V., 2018. Enhanced Activity of $\mathrm{TiO}_{2}$ /Natural Zeolite Composite for Degradation of Methyl Orange under Visible Light Irradiation. International Journal of Technology, Volume 9(6), pp. 1159-1167

Rakhmawaty, D., Putra, D.A., 2011. Fotodegradasi Methylene Blue Menggunakan Fotokatalis $\mathrm{TiO}_{2} /$ Zeolit Alam. Presiding Seminar Nasional Kimia dan Pendidikan Kimia III (Methylene Blue Photodegradation by using $\mathrm{TiO}_{2} /$ Natural Zeolite Photocatalysts. The National Seminar Proceeding of Chemistry and Chemistry Education III). pp. 255-264, Program Studi Pendidikan Kimia Jurusan Pendidikan MIPA, FKIP, Universitas Sebelas Maret Surakarta, Surakarta

Razzak, M.T., Las, T., Priyambodo, 2013. The Characterization of Indonesian's Natural Zeolite for Water Filtration System. Jurnal Kimia Valensi, Volume 3(2), pp. 129-137

Rusydi, A.F., Suherman, D., Sumawijaya, N., 2016. Pengolahan air Limbah Tekstil Melalui Proses Koagulasi-Flokulasi Dengan Menggunakan Lempung Sebagai Penyumbang Partikel Tersuspensi. Studi Kasus: Banaran, Sukoharjo dan Lawean, Kerto Suro, Jawa Tengah (Textile Wastewater Treatment through Coagulation-Flocculation Process using Clay as Contributor to Suspended Particles. Case Study: Banaran, Sukoharjo and Lawean, Kerto Suro, Central Java). Arena Tekstil, Volume 31(2), pp. 105-114

Salam, A., Agustina, T.E., Mohadi, R., 2018. Photocatalytic Degradation of Procion Red Synthetic Dye using ZnO-Zeolite Composites. International Journal of Scientific and Technology Research, Volume 7(8), pp. 54-59

Sharfan, N., Shobri, A., Anindria, F.A., Mauricio, R., Tafsili, M.A.B., Slamet, S., 2018. Treatment of Batik Industry Waste with a Combination of Electrocoagulation and Photocatalysis. International Journal of Technology, Volume 9(5), pp. 936-943 
Suhartana, Sukmasari, E., Azmiyawati, C., 2018. Modification of Natural Zeolite with Fe(III) and its Application as Adsorbent Chloride and Carbonate Ions. In: IOP Conference Series: Materials Science and Engineering, Volume 349, pp. 1-11

Takeda, N., Torimoto, T., Sampath, S., Kuwabata, S., Yoneyama, H., 1995. Effect of Inert Support for Titanium Dioxide Loading on Enhancement of Photodecomposition Rate of Gaseous Propionaldehyde. The Journal of Physical Chemistry, Volume 99, pp. 99869991

Vaiano, V., Matarangolo, M., Sacco, O., Sannino, D., 2017. Photocatalytic Removal of Eriochrome Black T Dye Over ZnO Nanoparticles Doped with Pr, Ce or Eu. Chemical Engineering Transactions, Volume 57, pp. 625-630

Viswanathan, B., 2018. Photocatalytic Degradation of Dyes: An Overview. Current Catalysis, Volume 7(1), pp. 1-25

Wang, S., Peng, Y., 2010. Natural Zeolites as Effective Adsorbents in Water and Wastewater Treatment. Chemical Engineering Journal, Volume 156(1), pp. 11-24

Widiyastuti, W., Maula, I., Nurtono, T., Taufany, F., Machmudah, S., Winardi, S., Panatarani, C., 2014. Preparation of Zinc Oxide/Silica Nanocomposite Particles via Consecutive Sol-Gel and Flame-Assisted Spray-Drying Methods. Chemical Engineering Journal, Volume 254, pp. 252-258

Winatapura, D.S., Dewi, S.H., Adi, W.A., 2016. Synthesis Characterization, and Photocatalytic Activity of $\mathrm{Fe}_{3} \mathrm{O}_{4} @ \mathrm{ZnO}$ Nano Composite. Internasional Journal of Technology, Volume 7(3), pp. 408-416

Wismayanti, D.A., Diantariani, N.P., Santi, S.R., 2015. Pembuatan Komposit ZnO-Arang Aktif sebagai Fotokatalis untuk Mendegradasi Zat Warna Metilen Biru (Preparation of ZnOActive Charcoal Composites as Photocatalysts to Degrade Methylene Blue Dye). Jurnal Kimia, Volume 9(1), pp. 109-116

Wulandari, D.A., Nasruddin, Djubaedah, E., 2019. Selectivity of Water Adsorbent Characteristic on Natural Zeolite in Cooling Application. Journal of Advanced Research in Fluid Mechanics and Thermal Sciences, Volume 55(1), pp. 111-118

Zhao, L., Liu, Z.C., Liu, Z.F., 2015. Synthetic Zeolite Supported ZnO Nanoparticle Materials for Photocatalytic Applications. Energy Materials: Materials Science and Engineering for Energy Systems, Volume 10(2), pp. 60-64 